\title{
Cathepsin K and Its Specific Target in Mediating Breast Cancer Skeletal Metastasis
}

\author{
Yaongamphi Vashum ${ }^{1, *}$, Zenith Khashim², Fathima Bushra Sheriff $\mathbf{M}^{3}$ \\ ${ }^{1}$ Department of Biochemistry, Armed Forces Medical College, Pune, Maharashtra, India \\ ${ }^{2}$ Department of Physiology and Biomedical Engineering, Mayo Clinic, Rochester MN 55905, USA \\ ${ }^{3}$ Department of Biochemistry, VRR Institute of Biomedical Science (Affiliated to University of Madras), Chennai - 600056 , India
}

Received March 26, 2020; Revised May 26, 2020; Accepted June 4, 2020

Copyright $\odot 2020$ by authors, all rights reserved. Authors agree that this article remains permanently open access under the terms of the Creative Commons Attribution License 4.0 International License

\begin{abstract}
Cathepsin K (CTSK), a cysteine protease predominantly seen in osteoclasts, degrades protein present in the organic matrix of bone inducing bone resorption. Based on the accumulating evidences, CTSK has an established role in osteoclast mediated bone resorption, progression of cancer invasion, migration and extracellular matrix degradation through activating several pathways, which vary from other classes of cysteine proteinases such as Cathepsin B \& L. Studies in the past have shown that CTSK is a key protease in breast cancer-induced bone metastases which are found highly expressed in human breast and prostate carcinomas. However, the involvement of CTSK in breast and prostate cancer development remains unclear. Bone is a key site of breast and prostate cancer metastasis and most patients with advanced disease encounter complications from incurable bone lesions. Therefore, CTSK can be viewed as an alternative target for treating patients with metastatic bone disease. This review discusses the molecular insights into CTSK and its specific targets in mediating breast cancer skeletal metastasis, so as to find the novelty of cathepsin K therapeutic target for the treatment of patients with osteolytic bone metastases.
\end{abstract}

Keywords Cathepsin k, Breast Cancer, Skeletal Metastasis, Extracellular Matrix, Cathepsin K Inhibitor

\section{Introduction}

A skeletal lesion of metastatic bone disease adds significant extent to morbidity and mortality in patients with breast cancer. Cancer cells metastasize to the bone and stimulate the function of bone degrading cell osteoclast, which releases proteases to initiate osteolytic lesions [1]. Multitudes of proteins are involved in bone metastasis; cathepsins known as lysosomal cysteine proteases are one among the proteins that are involved in the bulk degradation of intracellular and endocytosed proteins. This process of degradation is required for cancer cells to travel through the basal lamina, which is the hallmark of malignancy [2].

Cathepsins are a group of lysosomal proteases which play a key role in cellular protein turnover. Cathepsins alter general proteolytic activity through interactions with other proteases and their inhibitors within the tumor microenvironment (3). Several families of cathepsins namely B, L, H, X, S, and K have been suggested to play an important role in tumor progression, invasion/metastasis and angiogenesis.

The role of cathepsins B and L in several human carcinomas and their association with prognosis has been well reported in earlier research [4-5]. In this way, cathepsins $\mathrm{B}$ and $\mathrm{L}$ have gained considerable interest among the cathepsins because of their attributed role in cancer progression [6]. The contribution of cathepsins to the development of cancer is primarily due to the processing of extracellular matrix proteins, the processing of chemokine and the shedding of cell surface molecules, thereby allowing the cancer cells to migrate and invade other organs $[7,8]$. CTSK are able to hydrolyze peptide bonds of triple helical type I and II collagens which constitute approximately $90 \%$ of the bone matrix with higher efficiency as compared with other cathepsins and matrix metalloproteinases (MMPs). It is also found that the elastinolytic activity of CTSK is higher than that of pancreatic elastase [9-10]. This unique specificity makes a significant support to the degradation of bone matrix especially in breast cancer induced osteolysis [11]. CTSK has been observed in almost all primary tumor sarcomas [12-22], carcinoma [23-29] in addition to the high expression in osteoclasts, showing its potential diagnostic and prognostic impact in metastatic cancer. Accumulating evidence suggests that CTSK in association with other proteinases such as cathepsin $\mathrm{B}$, matrix metalloproteinases (MMPs) and urokinase type plasminogen activator (uPA), 
could facilitate cancer progression [30-31]. CTSK degrades the ECM components, including osteonectin, vascular endothelial growth factor (VEGF), adiponectin, osteopontin, and stromal cell derived factor 1 (SDF1) in addition to cleavage of Type I \& II collagen. This cleavage results in alteration of signaling within the niche to loosen the anchorage of stem cells to the extracellular matrix (ECM) [32]. The degradation of ECM components releases biologically active molecules that can influence epithelial cell proliferation, migration and regulate organ morphogenesis [33]. Several studies also point to the significant release of ECM components due to proteolytic cleavage in promoting the growth of metastatic tumor cells in the metastatic niche [34,35,36]. Remodeling of ECM occurs at an early step in metastasis to help colonize and survive in distant organs in circulating tumor cells.

In addition, degradation of the ECM also releases ECM-bound growth factors such as VEGF, facilitating angiogenesis, activation of progenitor cells and anchoring of metastatic cancer cells to the bone [37-40].

Several studies in the field of cancer bone metastases have now based their attention on this protein, perhaps underscoring the potential involvement of other proteinases of this family. As known, CTSK plays a crucial role in ECM degradation and extracellular matrix remodeling, which makes a significant contribution to the tumor metastasis. It is well documented by many experimental and clinical observations, which highlight, that the expression levels of this proteinase are up regulated in bone diseases associated bone resorption including cancer induced osteolysis (16-17) and that the administration of selective CTSK inhibitor prevent cancer induced bone resorption and bone metastasis in human trial and animal model studies[40-46].

\section{CTSK Mechanism of Action in Bone Metastasis}

CTSK high collagenolytic and elastolytic activity plays a vital role in mediating bone resorption by degrading structural components of extracellular matrix (e.g., collagen or elastin) [47-49]. CTSK has been found to be involved in the production of cytokines and chemokines beyond basic proteolysis, thus providing a significant link between inflammation and diseases such as cancers [50-54]. In addition, more specific functions of cathepsins were reported recently, shedding a group of extracellular receptors and cell adhesion molecules, demonstrating that their limited extracellular proteolysis could not only directly impact the cell surface but also influence intracellular signaling pathways (e.g., kinase receptor signaling), thereby contributing to the disease progression [21].

Increased expression of pro-inflammatory cytokines correlates with protease upregulation as in many cases cytokines requires proteolytic activation in the tumor microenvironment [55]. Molecular genetic studies employing knock-out studies and transgenic animals provide the major pieces of evidence that are most persuasive and clearly establish the function and involvement of CTSK in metastatic cascade $(56,57)$. These studies support the specific functional mechanisms for both tumor and stromal CTSK during distinct metastatic cascade phases, and suggest that CTSK may exhibit pro-metastatic roles depending on their existence and experimental environment [58].

Increased expression of CTSK in endothelial progenitor cells causes cleavage of Notch1 (c-Notch1), Hes1 Hey1, Hey2 according to Jiang et al. ${ }^{59}$ studies. The study suggests that CTSK plays a functional role in ischaemia-induced neovascularization. In the same study, indicate, In a mice CTSK deficiency decreases the levels of Notch1 (c-Notch1), Hes1 Hey1, Hey2, vascular endothelial growth factor, Flt-1 and isc phospho-Akt proteins. Suggesting CTSK contributes to Notch1 processing and activates downstream signalling. In addition, CTSK knockdown leads to defective endothelial cell invasion, proliferation, and tube formation. CTSK deficiency is also associated with reduced circulation of $\mathrm{CD} 31+/ \mathrm{c}-\mathrm{Kit}+-$ like endothelial progenitor cells in mice following hindlimb ischaemia. By this we can conclude that CTSK also has a vital role in angiogenesis and vasculogenesis.

Cysteine proteases cleaves and activates several growth factors including vascular endothelial growth factor, platelet-derived growth factor, and fibroblast growth factor-2, and eventually leads to enhancement of tumor-associated angiogenesis $[60,61]$. In addition to being a potent collagenase, cleavage of osteopontin, osteonectin, aggrecan, thyroglobulin and an insulin-like growth factor-1 by CTSK have also been reported [62]. Cleavage and subsequent activation of IGF-1 promotes differentiation of myofibroblast and induces fibroblast level [63-64]. Fibroblast increases the expression of MMP1 and MMP3 which are capable of cleaving E-cadherin thereby promoting migration and invasion of tumor [60,65].

Additional studies are compellingly needed to identify the signaling pathways/molecular mechanisms by which CTSK trigger in the tumor microenvironment for a better understanding of their function and for effective therapeutic target. Overall, a correlative analysis of CTSK expression and its critical role during cancer development makes apparent the layered complexity of tumor metastasis and points to the fact that a simple link between elevated cathepsins expression, cancer progression and secondary metastasis is not really apparent or straightforward.

\section{Extracellular Matrix Degradation by CTSK and the Released of Matrix Factors}

Degradation of the extracellular matrix (ECM) is mainly regulated by common matrix metalloproteinases (MMPs) and their inhibitors (i.e., metalloproteinase tissue inhibitors 
(TIMPs) [31], disintegrin and thrombospondin-motivated metalloproteinase (ADAMTS) family of proteinases [55], and cysteine protease cathepsins [66]. ECM is commonly deregulated and is disorganized in cancer leading to cancer progression by directly promoting cellular transformation and metastasis. ECM abnormalities also deregulate the actions of stromal cells; promote tumor-associated angiogenesis and inflammation, leading to tumor-associated microenvironment generation $[67,68]$.

Cathepsins increase the activity of the matrix metalloproteinases by destroying their inhibitors, thereby promoting ECM degradation and angiogenesis [70]. Another significant factor leading to the ECM degradation mediated by extracellular cathepsins is the slightly acidic $\mathrm{PH}$ of the tumor microenvironment due to the glycolysis caused by hypoxia [71].

The ECM degradation mechanisms include loosening of cell-to-cell adhesion and extensive ECM remodeling, allowing for lateral movement of the escaped tumor cells along the ECM fibrils towards the blood vessel basement membrane $(72,73)$. Therefore, in addition to MMPs, cathepsins are thought to be catalytically involved in all of these processes but not well known to be active and essential participants. Different studies have shown that CTSK plays an important role in initiating a proteolytic cascade involving urokinase-type plasminogen activator (uPA), plasminogen, and plasmin [69,59].

The metastasis of breast cancer with respect to CTSK can be described in several steps (Figure 1). CTSK is one of those cathepsins directly associated with extracellular matrix degradation [60,74-76]. It also activates proteolytic cascade and upregulate the expression of matrix metalloproteinases and plasminogen urokinase activator (uPA), resulting in further tissue invasion [59]. CTSK and MMP-9 together are involved in a protease-signaling network [60]. CTSK cleaves and activates proMMP-9 under acidic conditions as the tumor environment is inherently acidic due to a high rate of glycolysis (Warburg Effect) promoting cancer invasion and angiogenesis $[77,78]$.

Osteonectin (ON) also known as secreted protein acidic and rich in cysteine (SPARC) is a matrix protein that undergoes proteolytic processing that result in a number of physiological and pathological functions [79-80]. CTSK has shown to be capable of cleaving SPARC, a calcium binding glycoprotein [79] and a cell-matrix interaction modulator [82-83]. One study highlighted that cleavage of this protein may spread the progression of the bone tumor; through the release of proinflammatory factors into the tumor microenvironment [83].Other author indicate that the cleavage products control many growth factors including vascular endothelial growth factor, platelet-derived growth factor, and fibroblast growth factor-2, leading to tumor-associated angiogenesis enhancement [84-85]. Increased SPARC cleavage is associated with an invasive phenotype, and also promotes homing of tumor cells to the bone in prostate cancer [86-87]. Therefore, SPARC is considered as a marker of aggressiveness and poor prognosis in the overwhelming majority of human cancers [88-91].

In addition, CTSK is capable of cleaving VEGF and thereby potentially modulating its function. Similar to SPARC, VEGF levels are elevated when prostate carcinoma cells associate with human bone marrow cells and coincide with overexpression of CTSK. This indicates a possible involvement of CTSK in VEGF regulation, an occurrence which could promote osteoclasts recruitment and facilitate invasion in cancer diseases [92].CTSK cleaves and activates MMP9, which in turn degrades adhesion molecules like E-cadherin, thus promoting tumor migration and invasive capacity [93-94] as described in table 1. 
Table 1. Possible mechanism by which CTSK could facilitate Breast cancer bone metastasis formation

\begin{tabular}{|c|c|c|}
\hline Mechanism & Effects & References \\
\hline Bone matrix degradation & Invasion and metastasis & $6,92,40,126,127$ \\
\hline $\begin{array}{l}\text { CTSK, Cytokines (IL8,IL-11,RANKL),PTHrP released by } \\
\text { tumor cells metastasize to bone where it functions in } \\
\text { proteolytic pathways that facilitate cancer cell invasion. }\end{array}$ & $\begin{array}{l}\text { Bone matrix degradation; invasion and } \\
\text { metastasis }\end{array}$ & 65,60 \\
\hline $\begin{array}{l}\text { Activation of dormant precursor forms of other proteolytic } \\
\text { enzymes involved in metastatic cascade (MMPs, uPA) }\end{array}$ & $\begin{array}{l}\text { Extracellular matrix degradation, forms } \\
\text { of other proteolytic Invasion and } \\
\text { metastasis }\end{array}$ & 31 \\
\hline $\begin{array}{l}\text { ECM degradation products SPARC, } \\
\text { Elastin,aggrecan,osteopontin,proteoglycans and the release of } \\
\text { tumour growth factors -IGF-,TGF } \beta, F G F\end{array}$ & progression/invasiveness of the tumor & $\begin{array}{c}2,6,7,12,46,128,81,129,130 \\
, 131\end{array}$ \\
\hline Degradation of E-cadherin & $\begin{array}{l}\text { Reduced adhesion, increased motility } \\
\text { and migration of cancer cells }\end{array}$ & $132,133,94,60$ \\
\hline $\begin{array}{l}\text { Increased expression of CTSK in endothelial progenitor cells } \\
\text { causes cleavage of Notch1 (c-Notch1), Hes1 Hey1, Hey2 }\end{array}$ & $\begin{array}{c}\text { Tissue remodeling and tumor } \\
\text { neovascularization }\end{array}$ & 126 \\
\hline $\begin{array}{l}\text { Activation of proteolytic cascade matrix metalloproteinases } \\
\text { and urokinase plasminogen activator (uPA) }\end{array}$ & Tissue invasion & $134,135,136,57$ \\
\hline Cleavage of E-cadherin at adherin junctions, & $\begin{array}{l}\text { Detaching cells to enter circulation } \\
\text { and migrate }\end{array}$ & $86,137,138$ \\
\hline Activation of angiogenesis factors such as VEGF & $\begin{array}{l}\text { Activating signaling pathways involved } \\
\text { with angiogenesis, the formation of new } \\
\text { blood vessels from existing ones, further } \\
\text { mediating tumor progression and the } \\
\text { ability of cancer cells to enter circulation }\end{array}$ & $8,135,136$ \\
\hline
\end{tabular}

\section{CTSK as Drug Targets to Bone Metastasis in Breast Cancer}

Over the past few years, the field of CTSK inhibitors has progressed steadily from biological hypothesis, concept proof, and advanced clinical trials that claimed CTSK inhibition would be highly important to bone disease treatment [95-103]. For the indication of osteoporosis or bone metastasis, several CTSK inhibitors have been developed. None of these have entered the stage where it has been reviewed or approved for clinical use. There are several pharmaceutical companies actively conducting clinical trials to date. Example balicatib has been shown to have an efficacy on bone mineral density (BMD) in postmenopausal women with low bone density; AFG-495, a nitrile- Novartis compound, and MIV-701/710, a Medivir compound [104,105]. Relacatib (SB-462795) is an oral compound which was studied intensively by GlaxoSmithKline. It is a monobasic, $\alpha$-heteroatomic cyclic ketone which acts non-selectively on $\mathrm{K}, \mathrm{L}$, and $\mathrm{V}$ cathepsin $[106,107]$. However, due to its poor selectivity in inhibition these drugs were halted after phase I and phase II trials [108].

Numerous studies on the development of CTSK inhibitors in which all the substratum-binding subsites and various warheads, have been explored. This work leads to the conclusion that the most promising compounds are the nitriles (developed by Novartis and Merck) and ketones, such as the compound GlaxoSmithKline SB-462795, which is a cyclic ketone $\alpha$-heteroatom [108-111] .This, has recently led to the assertion that CTSK is an "undruggable" prototypical target as defined by its binding site structure [106]. This estimate is based on a measurement of the "absolute achievable noncovalent binding affinity" for a drug-like compound, which illustrates the challenge of achieving sufficient binding energy in the broad, relatively shallow active site. Recently, twelve commercial and non-commercial CTSK inhibitors have been described in a series of enzyme and cell-based assays to gain an unbiased view of their selectivity profiles [112]. Taking advantage of the binding energy provided by the formation of a covalent bond between the inhibitor and the active cysteine site will be the ideal option to resolve these challenges. Hence the selectivity problem is of considerable importance in developing a CTSK inhibitor to reduce the risk of unnecessary adverse effects in a clinical environment. The latest efforts are primarily aimed at developing new appropriate CTSK inhibitors that may be free of potential side effects (56).

Recently, CTSK inhibitor, namely Odanacatib (ODN) (Merck \& Co. Inc.), has shown sufficient efficacy and safety. ODN is a highly selective CTSK inhibitor, and was studied for osteoporosis treatment but discontinued in phase 3 trials due to increased risk of stroke [113-114]. Studies of the Preclinical Model indicate that ODN has potential to prevent and treat $\mathrm{BC}$ bone metastasis [115].However, CTSK effects on cancer metastasis is still uncertain and no molecular level analysis has been performed so far, and with this consideration, it is an ongoing work intended to further understand its potential mechanisms in skeletal metastasis by using its selective inhibitor. 


\section{A. Extracellular Matrix Degradation}

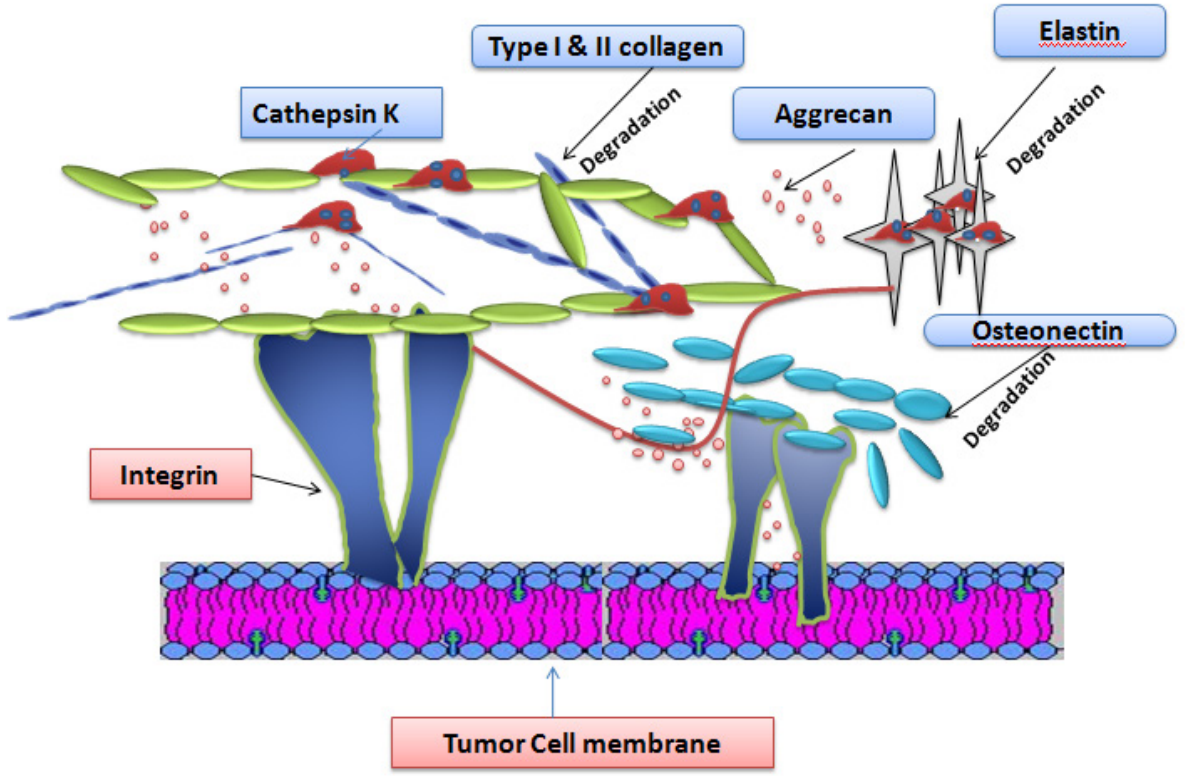

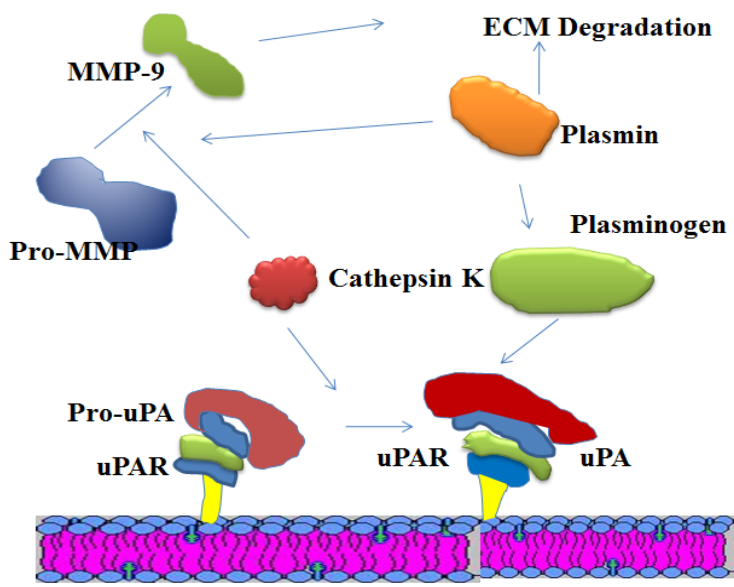

B. Proteolytic cascade

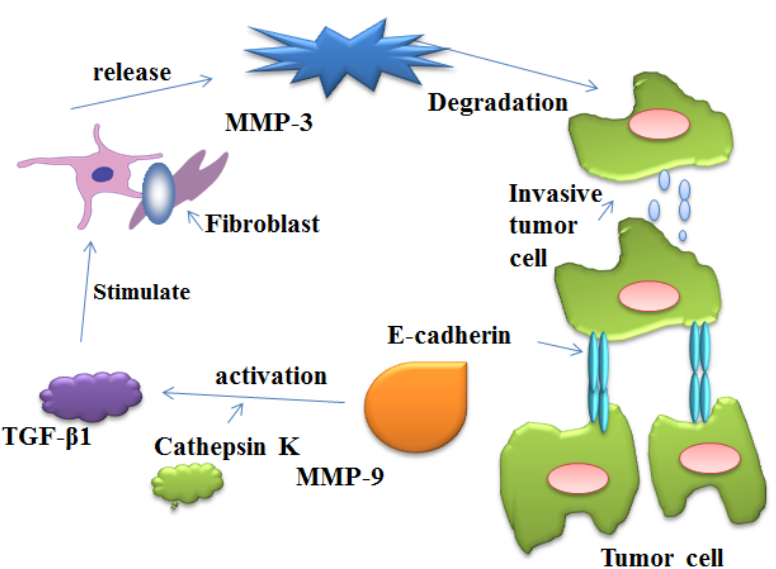

C. Tumor cell invasion

Figure 1. Breast cancer metastasis and CTSK. (a): CTSK directly degrades ECM constituents such Type I \& II collagen [117,124], Elastin [118,119] and Osteonectin[120]Aggrecan[121]. (b): CTSK converts both pro-MMP and pro-uPA to MMP 9 and uPA which results in a proteolytic cascade of further ECM degradation [41]. (c): CTSK cleaves and activate IFG-1 [122] IFG- 1 which activates fibroblasts [62,63]. Fibroblasts release MMP3 which degrades an adhesion molecule E-cadherin facilitating tumor migratory and invasive ability $[60,123]$

\section{Conclusions and Future Perspectives}

In this study, we provided an insight into the role of lysosomal protease CTSK in bone metastasis, with a focus on ECM degradation, proteolytic cascade activation, and tumor progression [Figure1]. Looking back on the progress that has been made with CTSK targeted therapies; we cannot conclude that we have been extraordinarily successful. Additional studies are absolutely necessary to verify CTSK and its specific target for better clinical approaches to treat cancers and metastasis. In the past, numerous researches have shown the contribution of CTSK towards tumor progression in skeletal tissue [116-117]. This has also suggested that the inhibition of
CTSK may be successful in the prevention and/or eradication of bone metastases. In addition, clinical evidence also indicates co-adjuvant therapy with CTSK inhibitors can effectively minimize bone metastasis formation. Since the outgrowth of osteolytic lesions involves activation of signaling pathways in both cancer cells and cells residing in the bone microenvironment, it is possible that combined therapeutic strategies targeting both compartments would be required to remove the cancer from invasion and progression. Some new therapeutic targets are expressed in bone metastases, or act to change the behavior of bone cells and cancer cells. This knowledge allows for a rare therapeutic opportunity to cripple the development of bone metastasis by using a single agent 
with multiple modes of action. Kappa-B ligand (RANKL) nuclear factor activator and CTSK activity are primarily needed for differentiation and functioning of osteoclasts, and current research suggests that inhibition of these molecules can lead to better antiresorptive strategies than some bisphosphonates in the treatment of bone metastasis and perhaps, in the treatment of breast cancer patients with advanced disease [109]. Ideally, demonstrating the detailed molecular mechanism of action will make it easier to recognize and validate molecules such as CTSK as important metastatic drug targets and to develop effective and safe drugs against bone metastasis. A brief analysis of the CTSK mechanism of action on skeletal metastasis will unravel the clinical benefit for therapeutic treatment of patients with skeletal metastasis of breast cancer and other cancer involving CTSK protease. More research will be required to describe and illustrate in depth the cleavage of SPARC, VEGF and MMPs by CTSK, its novel cleavage products and the biological consequences thereof which assist in cancer metastases. Overall, from the review of literature, it is evident that CTSK has numerous biological roles in cancer progression and the metastatic process. The CTSK broad influence on diverse aspects of tumor survival and growth makes it an attractive cancer therapy target. It is also clear that targeting CTSK has a major therapeutic advantage in alleviating pain, bone damage and reducing tumor growth in skeletal tissue.

\section{REFERENCES}

[1] Shupp AB, Kolb AD, Mukhopadhyay D, Bussard KM. Cancer Metastases to Bone: Concepts, Mechanisms, and Interactions with Bone Osteoblasts. Cancers, 10(6):182, 2018.

[2] Hanahan D, Weinberg RA. The hallmarks of cancer. Cell, 100(1):57-70,2000

[3] Olson OC, Joyce JA. Cysteine cathepsin proteases: regulators of cancer progression and therapeutic response. Nat Rev Cancer, 15(12):712-729, 2015.

[4] Roshy S, Sloane BF, Moin K. Pericellular cathepsin B and malignant progression. Cancer Metastasis Rev, 22:271-286, 2003

[5] Rudzińska, M., Parodi, A., Soond, S. M., Vinarov, A. Z., Korolev, D. O., Morozov, A. O., Daglioglu, C., Tutar, Y., \& Zamyatnin, A. A., Jr. "The Role of Cysteine Cathepsins in Cancer Progression and Drug Resistance." International journal of molecular sciences, 20(14):3602, 2019.

[6] N. Aggarwal and B. F. Sloane, Cathepsin B: multiple roles in cancer, Proteomics: Clin. Appl., 8: 427 437, 2014.

[7] Gocheva, V., Zeng, W., Ke, D., Klimstra, D., Reinheckel, T., Peters, C., Hanahan, D., \& Joyce, J. A. Distinct roles for cysteine cathepsin genes in multistage tumorigenesis, Genes Dev. 20, 543 — 556,2006.
[8] U. Repnik, A. E. Starr, C. M. Overall and B. Turk, Cysteine Cathepsins Activate ELR Chemokines and Inactivate Non-ELR Chemokines, J. Biol. Chem,290:13800 $-13811,2015$.

[9] Kafienah W, Bromme D, Buttle DJ, Croucher LJ, Hollander AP. Human Cathepsin $\mathrm{K}$ cleaves native type I and II collagens at the $\mathrm{N}$-terminal end of the triple helix. Biochem J, 331:727-732, 1998 .

[10] Garnero P, Borel O, Byrjalsen I, Ferreras M, Drake FH, MS, Foged NT, Delmas PD, Delaisse JM.The collagenolytic activity of Cathepsin $\mathrm{K}$ is unique among mammalian proteinases. J Biol Chem, 273:32347-32352, 1998.

[11] Brubaker KD, Vessella RL, True LD, Thomas R, and Corey E. CTSK mRNA and protein expression in prostate cancer progression. J Bone Miner Res. 18, 222-230, 2003.

[12] Lindeman, J. H., Hanemaaijer, R., Mulder, A., Dijkstra, P. D., Szuhai, K., Bromme, D., Verheijen, J. H., \& Hogendoorn, P. C. Cathepsin K is the principal protease in giant cell tumor of bone. Am J Pathol 165:593-600, 2004.

[13] Husmann K, Muff R, Bolander ME, Sarkar G, Born W, Fuchs B. Cathepsins and osteosarcoma: expression analysis identifies CTSK as an indicator of metastasis. Mol Carcinog 73:66-73, 2008.

[14] Martignoni, G., Bonetti, F., Chilosi, M., Brunelli, M., Segala, D., Amin, M. B., Argani, P., Eble, J. N., Gobbo, S., \& Pea, M. Cathepsin K expression in the spectrum of perivascular epithelioid cell (PEC) lesions of the kidney. Mod Pathol, 25:100-11, 2012.

[15] Rao, Q., Cheng, L., Xia, Q. Y., Liu, B., Li, L., Shi, Q. L., Shi, S. S., Yu, B., Zhang, R. S., Ma, H. H., Lu, Z. F., Tu, P., \& Zhou, X. J. Cathepsin K expression in a wide spectrum of perivascular epithelioid cell neoplasms (PEComas): a clinicopathological study emphasizing extrarenal PEComas. Histopathology, 62:642-50, 2013.

[16] Martignoni, G., Gobbo, S., Camparo, P., Brunelli, M., Munari, E., Segala, D., Pea, M., Bonetti, F., Illei, P. B., Netto, G. J., Ladanyi, M., Chilosi, M., \& Argani, P. Differential expression of Cathepsin $\mathrm{K}$ in neoplasms harboring TFE3 gene fusions. Mod Pathol, 24:1313-9, 2011.

[17] Zheng, G., Martignoni, G., Antonescu, C., Montgomery, E., Eberhart, C., Netto, G., Taube, J., Westra, W., Epstein, J. I., Lotan, T., Maitra, A., Gabrielson, E., Torbenson, M., Iacobuzio-Donahue, C., Demarzo, A., Shih, I., Illei, P., Wu, T. C., \& Argani, P. A broad survey of Cathepsin K immunoreactivity in human neoplasms. Am J Clin Pathol, 139:151-9, 2013.

[18] Argani, P., Aulmann, S., Illei, P. B., Netto, G. J., Ro, J., Cho, H. Y., Dogan, S., Ladanyi, M., Martignoni, G., Goldblum, J. R., \& Weiss, S. W. A distinctive subset of PEComas harbors TFE3 gene fusions. Am J Surg Pathol, 34:1395-406, 2010.

[19] Littlewood-Evans, A. J., Bilbe, G., Bowler, W. B., Farley, D., Wlodarski, B., Kokubo, T., Inaoka, T., Sloane, J., Evans, D. B., \& Gallagher, J. A. The osteoclast-associated protease Cathepsin $\mathrm{K}$ is expressed in human breast carcinoma. Cancer Res, 57:5386-90, 1997. 
[20] Bühling, F., Waldburg, N., Gerber, A., Häckel, C., Krüger, S., Reinhold, D., Brömme, D., Weber, E., Ansorge, S., \& Welte, T. Cathepsin K expression in human lung. Adv Exp Med Biol, 477:281-6, 2000.

[21] Kleer, C. G., Bloushtain-Qimron, N., Chen, Y. H., Carrasco, D., Hu, M., Yao, J., Kraeft, S. K., Collins, L. C., Sabel, M. S., Argani, P., Gelman, R., Schnitt, S. J., Krop, I. E., \& Polyak, K.Epithelial and stromal Cathepsin K and CXCL14 expression in breast tumor progression. Hum Cancer Biol, 14:5357-67, 2008.

[22] Tumminello FM, Flandina C, Crescimanno M, Leto G. Circulating Cathepsin $\mathrm{K}$ and cystatin $\mathrm{C}$ in patients with cancer related bone disease: clinical and therapeutic implications. Biomed Pharmacother, 62:130-5, 2008.

[23] Chen B, Platt MO. Multiplex zymography captures stage-specific activity profiles of cathepsins $\mathrm{K}, \mathrm{L}$, and $\mathrm{S}$ in human breast, lung, and cervical cancer. J Transl Med, 9:109, 2011.

[24] Ishida M, Kojima F, Okabe H. CTSK expression in basal cell carcinoma. J Eur Acad Dermatology Venereol, 27:128-30, 2013.

[25] Quintanilla-Dieck MJ, Codriansky K, Keady M, Bhawan J, Rünger TM. CTSK in melanoma invasion. J Invest Dermatol, 128:2281-8, 2008 .

[26] Yan, X., Takahara, M., Xie, L., Oda, Y., Nakahara, T., Uchi, H., Takeuchi, S., Tu, Y., Moroi, Y., \& Furue, M. Stromal expression of CTSK in squamous cell carcinoma. J Eur Acad Dermatology Venereol, 25:362-5, 2011.

[27] Xie L, Moroi Y, Hayashida S, Tsuji G, Takeuchi S, Shan B. Cathepsin K-upregulation in fibroblasts promotes matrigel invasive ability of squamous cell carcinoma cells via tumor derived IL-1 a. J Dermatol Sci, 61:45-50,2011.

[28] Withana, N. P., Blum, G., Sameni, M., Slaney, C., Anbalagan, A., Olive, M. B., Bidwell, B. N., Edgington, L., Wang, L., Moin, K., Sloane, B. F., Anderson, R. L., Bogyo, M. S., \& Parker, B. S. Cathepsin B inhibition limits bone metastasis in breast cancer. Cancer Res, 72:1199-209, 2012.

[29] Levicar, N., Kos, J., Blejec, A., Golouh, R., Vrhovec, I., Frkovic-Grazio, S., \& Lah, T. T. Comparison of potential biological markers cathepsin B, cathepsin L, stefin A and stefin B with urokinase and plasminogen activator inhibitor-1 and clinicopathological data of breast carcinoma patients. Cancer Detect Prev, 26:42-9, 2002.

[30] Visse R and Nagase H. Matrix metalloproteinases and tissue inhibitors of metalloproteinases: structure, function, and biochemistry. Circ Res 92:827-839, 2003.

[31] Tang BL ADAMTS: a novel family of extracellular matrix proteases. Int J Biochem Cell Biol, 33:33-44,2001.

[32] Herroon MK, Rajagurubandara E, Rudy DL, Chalasani A, Hardaway AL, Podgorski I.Macrophage Cathepsin K promotes prostate tumor progression in bone. Oncogene, $32: 1580-93,2013$.

[33] Bonnans C, Chou J, Werb Z. Remodelling the extracellular matrix in development and disease. Nat Rev Mol Cell Biol,15(12):786-801,2014.

[34] Lu P, Weaver VM, Werb Z. The extracellular matrix: a dynamic niche in cancer progression. J Cell Biol, 196(4):395-406, 2012.

[35] Paolillo M, Schinelli S. Extracellular Matrix Alterations in Metastatic Processes. Int J Mol Sci, 20(19):4947,2019

[36] Walker C, Mojares E, Del Río Hernández A. Role of Extracellular Matrix in Development and Cancer Progression. Int J Mol Sci, 19(10):3028,2018

[37] Góth MI, Hubina E, Raptis S, Nagy GM, Tóth BE. Physiological and pathological angiogenesis in the endocrine system. Microsc Res Tech, 60(1):98-106,2003.

[38] Podgorski I, Linebaugh BE, Sloane BF. Cathepsin K in the bone microenvironment: link between obesity and prostate cancer? Biochem Soc Trans, 35:701-3,2007.

[39] Tumminello FM, Flandina C, Crescimanno M, Leto G. Circulating Cathepsin $\mathrm{K}$ and cystatin in patients with cancer related bone disease: clinical and therapeutic implications. Biomed Pharmacother, 62:130-5,2008.

[40] Le Gall, C., Bellahcène, A., Bonnelye, E., Gasser, J. A., Castronovo, V., Green, J., Zimmermann, J., \& Clézardin, P. A Cathepsin $\mathrm{K}$ inhibitor reduces breast cancer induced osteolysis and skeletal tumor burden. Cancer Res, 67:9894902,2007 .

[41] Grabowska U, Chambers TJ, Shiroo M. Recent developments in Cathepsin $\mathrm{K}$ inhibitor design.Curr Opin Drug Discov Devel. 8:619-30, 2005.

[42] Palmer, J. T., Bryant, C., Wang, D. X., Davis, D. E., Setti, E. L., Rydzewski, R. M., Venkatraman, S., Tian, Z. Q., Burrill, L. C., Mendonca, R. V., Springman, E., McCarter, J., Chung, T., Cheung, H., Janc, J. W., McGrath, M., Somoza, J. R., Enriquez, P., Yu, Z. W., Strickley, R. M., ... Rodan, G. Design and synthesis of tri-ring $\mathrm{P} 3$ benzamide-containing aminonitriles as potent, selective, orally effective inhibitors of Cathepsin K. J ,Med Chem, 48:7520-34, 2005.

[43] Le Gall C, Bonnelye E, Clézardin P. Cathepsin K inhibitors as treatment of bone metastasis. Curr Opin Support Palliat Care, 2:218-22, 2008.

[44] Jensen, A. B., Wynne, C., Ramirez, G., He, W., Song, Y., Berd, Y., Wang, H., Mehta, A., \& Lombardi, A. The Cathepsin $\mathrm{K}$ inhibitor odanacatib suppresses bone resorption in women with breast cancer and established bone metastases: resu ts of a 4-week, double-blind, randomized, controlled trial. Clin Breast Cancer, 10:4528,2010 .

[45] Fujii, T., Ishikawa, M., Kubo, A., \& Tanaka, Y. Effect of SI-591, a new class of cathepsin $\mathrm{K}$ inhibitor with peptidomimetic structure, on bone metabolism in vitro and in vivo. Bone vol, 81: 427-434, 2015.

[46] Wilson SR, Peters C, Saftig P, Bromme D: Cathepsin K activity dependent regulation of osteoclast actin ring formation and bone resorption. J. Biol. Chem, 284(4), 25842592, 2009.

[47] Gocheva V., Joyce J.A. Cysteine cathepsins and the cutting edge of cancer invasion. Cell Cycle, 6:60-64, 2007.

[48] Brömme D., Wilson S. Role of Cysteine Cathepsins in Extracellular Proteolysis. In: Parks W., Mecham R. (eds) Extracellular Matrix Degradation. Biology of Extracellular Matrix, vol 2. Springer, Berlin, Heidelberg, 2011. 
[49] Vizovisek M., Fonovic M., Turk B. Cysteine cathepsins in extracellular matrix remodeling: Extracellular matrix degradation and beyond. Matrix Biol, 75-76:141159,2019 .

[50] Repnik U., Starr A.E., Overall C.M., Turk B. Cysteine Cathepsins Activate ELR Chemokines and Inactivate Non-ELR Chemokines. J. Biol. Chem, 290:13800 13811,2015 .

[51] Ainscough, J. S., Macleod, T., McGonagle, D., Brakefield, R., Baron, J. M., Alase, A., Wittmann, M., \& Stacey, M. "Cathepsin S is the major activator of the psoriasis-associated proinflammatory cytokine IL-36 $\gamma . "$ Proceedings of the National Academy of Sciences of the United States of America, vol. 114, 13, 2017.

[52] Breznik B., Motaln H., Lah Turnsek T. Proteases and cytokines as mediators of interactions between cancer and stromal cells in tumours. Biol. Chem, 398:709-719, 2017.

[53] Ohashi K., Naruto M., Nakaki T., Sano E. Identification of interleukin-8 converting enzyme as cathepsin L. Biochim. Biophys. Acta, 1649:30-39, 2003.

[54] Hira, V. V., Verbovšek, U., Breznik, B., Srdič, M., Novinec, M., Kakar, H., Wormer, J., der Swaan, B. V., Lenarčič, B., Juliano, L., Mehta, S., Van Noorden, C. J., \& Lah, T. T. Cathepsin K cleavage of SDF-1alpha inhibits its chemotactic activity towards glioblastoma stem-like cells. Biochim. Biophys. Acta Mol. Cell Res, 1864:594-603, 2017.

[55] Leusink FK, Koudounarakis E, Frank MH, Koole R, van Diest PJ, Willems SM. Cathepsin K associates with lymph node metastasis and poor prognosis in oral squamous cell carcinoma. BMC Cancer, 18(1):385, 2018.

[56] Desmarais, S., Black, W.C., Oballa, R., Lamontagne, S., Riendeau, D., Tawa, P., Duong Le, T., Pickarski, M., and Percival, M.D. Effect of Cathepsin K inhibitor basicity on in vivo offtarget activities. Mol. Pharmacol,73, 147156,2008

[57] Duong LTLT, Wesolowski GA, Leung P, Oballa R, Pickarski M. Efficacy of a Cathepsin $\mathrm{K}$ inhibitor in a preclinical model for prevention and treatment of breast cancer bone metastasis. Mol Cancer Ther , 13:2898909,2014

[58] Nakasaki, M., Yoshioka, K., Miyamoto, Y., Sasaki, T., Yoshikawa, H., and Itoh, K. IGF-I secreted by osteoblasts acts as a potent chemotactic factor for osteoblasts. Bone, 43, 869-879, 2008

[59] Jiang H, Cheng XW, Shi GP, Hu L, Inoue A, Yamamura Y, Wu H, Takeshita K, Li X,Huang Z, Song H, Asai M, Hao CN, Unno K, Koike T, Oshida Y, Okumura K, Murohara T, Kuzuya M. Cathepsin K-mediated Notch1 activation contributes to neovascularization in response to hypoxia. Nat Commun, 5:3838, 2014.

[60] Brömme D, Okamoto K, Wang BB, Biroc S. Human cathepsin $\mathrm{O} 2$, a matrix protein-degrading cysteine protease expressed in osteoclasts. Functional expression of human cathepsin $\mathrm{O} 2$ in Spodoptera frugiperda and characterization of the enzyme. J Biol Chem, 271(4):2126-2132.1996.

[61] Bossard, M. J., Tomaszek, T. A., Thompson, S. K., Amegadzie, B. Y., Hanning, C. R., Jones, C., Kurdyla, J. T.,
McNulty, D. E., Drake, F. H., Gowen, M., \& Levy, M. A. Proteolytic activity of human osteoclast cathepsin K. Expression, purification, activation, and substrate identification. J Biol Chem, 271(21):12517-12524, 1996.

[62] Hiraga T, Myoui A, Hashimoto N, Sasaki A, Hata K, Morita Y, Yoshikawa H, Rosen CJ, Mundy GR, Yoneda T. Bone-derived IGF mediates crosstalk between bone and breast cancer cells in bony metastases. Cancer Res,72(16):4238-49, 2012.

[63] Nomura T, Katunuma N. Involvement of cathepsins in the invasion, metastasis and proliferation of cancer cells. J Med Invest, 52:1-9, 2005

[64] Roodman GD. Mechanisms of bone metastasis. N Engl J Med. 350:1655-64, 2004.

[65] Condeelis J, Singer R, Segall JE: The great escape: When cancer cells hijack the genes for chemotaxis and motility. Annu Rev Cell Dev Biol, vol. 21: 695-718, 2005.

[66] M.Stubbs P.M McSheehy, J.R Griffiths,C.L Bashford causes and consequences of tumour acidity and implications for treatment. Mol.Med.Today , 6(2000)15-19.

[67] Stubbs, M., McSheehy, P. M., Griffiths, J. R., \& Bashford, C. L. "Causes and consequences of tumour acidity and implications for treatment." Molecular medicine today, vol. 6,1: $15-9,2000$

[68] Christensen and Shastri Matrix-metalloproteinase-9 is cleaved and activated by Cathepsin K. BMC Res Notes, 8:322, 2015.

[69] Ahn GO, Brown JM. Matrix metalloproteinase-9 is required for tumor vasculogenesis but not for angiogenesis: role of bone marrowderived myelomonocytic cells. Cancer Cell, 13(3):193-205,2008.

[70] Kostoulas G, Lang A, Nagase H, Baici A. Stimulation of angiogenesis through cathepsin $\mathrm{B}$ inactivation of the tissue inhibitors of matrix metalloproteinases. FEBS Lett, 455:286-90, 1999.

[71] Everts V, van der Zee E, Creemers L, Beertsen W. Phagocytosis and intracellular digestion of collagen, its role in turnover and remodelling. Histochem J, (4):229-45, 1996.

[72] Walker C, Mojares E, Del Río Hernández A. Role of Extracellular Matrix in Development and Cancer Progression. Int J Mol Sci,19(10):3028,2018.

[73] Lu P, Takai K, Weaver VM, Werb Z. Extracellular matrix degradation and remodeling in development and disease. Cold Spring Harb Perspect Biol, 3(12), 2011.

[74] Garnero P, Borel O, Byrjalsen I, Ferreras M, Drake FH, McQueney MS, Foged NT, Delmas PD, Delaisse JM. The collagenolytic activity of CTSK is unique among mammalian proteinases. J Biol Chem, 273:32347-32352, 1998.

[75] Xia L, Kilb J, Wex H, Lipyansky A, Breuil V, Stein L, Palmer JT, Dempster DW, Bromme D. Localization of rat CTSK in osteoclasts and resorption pits: Inhibition of bone. resorptionCTSK-activity by peptidyl vinyl sulfones. Biol Chem, 380:679-687, 1999.

[76] Rolli M, Fransvea E, Pilch J, Saven A, Felding-Habermann 
B. Activated integrin alphavbeta3 cooperates with metalloproteinase MMP-9 in regulating migration of metastatic breast cancer cells. Proc Natl Acad Sci USA, 100(16):9482-9487, 2003.

[77] Lane TF, Sage EH. The biology of SPARC, a protein that modulates cell-matrix interactions. FASEB J, 8:163-173, 1994.

[78] Tai IT, Tang MJ. SPARC in cancer biology: its role in cancer progression and potential for therapy. Drug Resist Updat 11:231-246, 2008 .

[79] Bossard MJ, Tomaszek TT, Thompson SK, Amegadzies BY, Hannings CR, Jones C, Kurdyla JT, Mc Nulty DE, Drake FH, Gowen M, Levy MA. Proteolytic activity of human osteoclast CTSK. Expression, purification, activation, and substrate identification. J Biol Chem, 271:12517-12524, 1996.

[80] Motamed K: SPARC (osteonectin/BM-40). Int J Biochem Cell Biol. 31:1363-1366, 1999.

[81] Sasaki T, Gohring W, Mann K, Maurer P, Hohenester E, Knauper V, Murphy G, Timpl R: Limited cleavage of extracellular matrix protein $\mathrm{BM}-40$ by matrix metalloproteinases increases its affinity for collagens. J Biol Chem, 272:9237-9243, 1997.

[82] Podgorski I. Future of antiCTSK drugs: dual therapy for skeletal disease and atherosclerosis? Future Med Chem, 1:21-34,2009.

[83] Tai IT, Tang MJ: SPARC in cancer biology: its role in cancer progression and potential for therapy. Drug Resist Updat, 11:231-246,2008.

[84] Lane TF, Iruela-Arispe ML, Johnson RS, Sage EH: SPARC is a source of copper-binding peptides that stimulate angiogenesis. J Cell Biol, 125:929-943,1994.

[85] De S, Chen J, Narizhneva NV, Heston W, Brainard J, Sage $\mathrm{EH}$, Byzova TV: Molecular pathway for cancer metastasis to bone. J BiolChe, 278:39044-39050,2003.

[86] Jacob K, Webber M, Benayahu D, Kleinman HK: Osteonectin promotes prostate cancer cell migration and invasion: a possible mechanism for metastasis to bone. Cancer Res, 59:4453-4457, 1999.

[87] Mott, J.D., and Z. Werb.Regulation of matrix biology by matrix metalloproteinases. Biol. 16:558-564, 2004.

[88] Clark CJ, Sage EH: A prototypic matricellular protein in the tumor microenvironment-where there's SPARC, there's fire. J Cell Biochem, 104:721-732, 2008.

[89] Framson PE, Sage EH: SPARC and tumor growth: where the seed meets the soil? J Cell Biochem, 92:679-690, 2004.

[90] Koblinski JE, Kaplan-Singer BR, VanOsdol SJ, Wu M, Engbring JA, Wang S, Goldsmith CM, Piper JT, Vostal JG, Harms JF, Welch DR, Kleinman HK: Endogenous osteonectin/SPARC/BM-40 expressioninhibitsMDA-MB-231 breast cancer cell metastasis. Cancer Res, 65:7370-7377, 2005.

[91] Arampatzidou M, Schütte A, Hansson GC, Saftig P, Brix K. Effects of CTSK deficiency on intercellular junction proteins, luminal mucus layers, and extracellular matrix constituents in the mouse colon. Biol Chem,
393(12):1391-403, 2012.

[92] Podgorski I, Linebaugh BE, Sloane BF. Cathepsin K in the bone microenvironment: link between obesity and prostate cancer. Biochem Soc Trans, 35:701-3, 2007.

[93] Garnero, P., Borel, O., Byrjalsen, I., Ferreras, M., Drake, F. H., McQueney, M. S., Foged, N. T., Delmas, P. D., \& Delaissé, J. M. The collagenolytic activity of CTSK is unique among mammalian proteinases. J. Biol. Chem, 273, 32347-32352, 1998

[94] Morko JP, Soderstrom M, Saamanen AM, Salminen HJ, Vuorio EI.Up regulation of CTSK expression in articular chondrocytes in a transgenic mouse model for osteoarthritis. Ann Rheum Dis, 63: 649-55.2004.

[95] Pelletier, J. P., Boileau, C., Brunet, J., Boily, M., Lajeunesse, D., Reboul, P., Laufer, S., \& Martel-Pelletier, J. The inhibition of subchondral bone resorption in the early phase of experimental dog osteoarthritis by licofelone is associated with a reduction in the synthesis of MMP-13 and Cathepsin K. Bone, 34: 527-38, 2004.

[96] Akers JC, Gonda D, Kim R, Carter BS, Chen CC. Biogenesis of extracellular vesicles (EV): Exosomes, microvesicles, retrovirus-like vesicles, and apoptotic bodies. J Neurooncol, 113:1-11, 2013.

[97] Nakano I. Engulfing losers by winners in cancer: do cancer stem cells catch eat-me signals from noncancer stem cells? Futur Oncol, 10:1335-8,2014.

[98] Smith RE, Farquhar MG. Lysosome function in the regulation of the secretory process in cells of the anterior pituitary gland. J Cell Biol,1:319-47,1966.

[99] Aits S, Jäättelä M. Lysosomal cell death at a glance. J Cell Sci,126:1905-12, 2013.

[100] Prasmickaite L, Høgset A, Selbo PK, Engesaeter BØ, Hellum M, Berg K. Photochemical disruption of endocytic vesicles before delivery of drugs: a new strategy for cancer therapy. Br J Cancer, 86:652-7, 2002.

[101] Mohamed MM, Sloane BF. Cysteine cathepsins: multifunctional enzymes in cancer. Nat Rev Cancer, 6:764 75, 2006.

[102] Bone, H. G., Dempster, D. W., Eisman, J. A., Greenspan, S. L., McClung, M. R., Nakamura, T., Papapoulos, S., Shih, W. J., Rybak-Feiglin, A., Santora, A. C., Verbruggen, N., Leung, A. T., \& Lombardi, A. Odanacatib for the treatment of postmenopausal osteoporosis: development history and design and participant characteristics of LOFT, the Long-Term Odanacatib Fracture Trial. Osteoporosis international: a journal established as result of cooperation between the European Foundation for Osteoporosis and the National Osteoporosis Foundation of the USA, 26(2), 699$712,2015$.

[103] Yamashita, D. S., Marquis, R. W., Xie, R., Nidamarthy, S. D., Oh, H. J., Jeong, J. U., Erhard, K. F., Ward, K. W., Roethke, T. J., Smith, B. R., Cheng, H. Y., Geng, X., Lin, F., Offen, P. H., Wang, B., Nevins, N., Head, M. S., Haltiwanger, R. C., Narducci Sarjeant, A. A., Liable-Sands, L. M., ... Veber, D. F. Structure activity relationships of 5-, 6-, and 7-methyl-substituted azepan-3-one Cathepsin K inhibitors. J. Med. Chem:49: 1597-1612, 2006.

[104] Kumar, S., Dare, L., Vasko-Moser, J. A., James, I. E., Blake, 
S. M., Rickard, D. J., Hwang, S. M., Tomaszek, T. Yamashita, D. S., Marquis, R. W., Oh, H., Jeong, J. U., Veber, D. F., Gowen, M., Lark, M. W., \& Stroup, G. A highly potent inhibitor of Cathepsin $\mathrm{K}$ (relacatib) reduces biomarkers of bone resorption both in vitro and in an acute model of elevated bone turnover in vivo in monkeys. Bone, 40:122-131, 2007.

[105] Katunuma, N., Tsuge, H., Nukatsuka, M., and Fukushima, M. Structure-based development of cathepsin L inhibitorsand therapeutic applications for prevention of cancer metastasis and cancer-induced osteoporosis. Adv. Enzyme Regul, 42:159-172,2002.

[106] Masarachia, P. J., Pennypacker, B. L., Pickarski, M., Scott, K. R., Wesolowski, G. A., Smith, S. Y., Samadfam, R., Goetzmann, J. E., Scott, B. B., Kimmel, D. B., \& Duong, L. $\mathrm{T}$. Odanacatib reduces bone turnover and increases bone mass in the lumbar spine of skeletally mature ovariectomized rhesus monkeys. J Bone Miner Res, 27: 509-523, 2012.

[107] Pennypacker BL1, Duong le T, Cusick TE, Masarachia PJ, Gentile MA, Gauthier JY, BlackWC, Scott BB, Samadfam R, Smith SY, Kimmel DB. CTSK inhibitors prevent bone loss in estrogen-deficient rabbits.J Bone Miner Res, 26(2):252-62, 2011

[108] Eastell, R., Nagase, S., Ohyama, M., Small, M., Sawyer, J., Boonen, S., Spector, T., Kuwayama, T., \& Deacon, S. "Safety and efficacy of the cathepsin K inhibitor ONO-5334 in postmenopausal osteoporosis: the OCEAN study." Journal of bone and mineral research: the official journal of the American Society for Bone and Mineral Research vol. 26(6): 1303-12, 2011.

[109] Gauthier JY, Chauret N, Cromlish W, Desmarais S, The discovery of odanacatib (MK-0822), a selective inhibitor of cathepsinK.Bioorg Med ChemLett, 1;18(3):923-8, 2008.

[110] Merck Sharp \&Dohme Corp. Efficacy and Safety of Odanacatib in Post-menopausal women previously treated with oral bisphosphonate (MK-0822-076)- Phase 3; ClinicalTrials.gov Identifier: NCT01803607; First received: February 28, 2013.Last updated: June 18, 2014.

[111] Tavares, F. X., Deaton, D. N., Miller, A. B., Miller, L. R. \& Wright, L. L. Ketoheterocycle-based inhibitors of Cathepsin K: a novel entry into the synthesis of peptidic ketoheterocycles. Bioorg. Med. Chem. Lett. 15:3891-3895, 2005 .

[112] Black, W.C. and Percival, M.D.The consequences of lysosomotropism on the design of selective CTSK inhibitors. ChemBioChem 7: 1525-1535, 2006.

[113] Cheng, A. C.; Coleman, R. G.; Smyth, K. T.; Cao, Q.; Soulard, P.; Caffrey, D. R.; Salzberg, A. C.; Huang, E. S. Structure-based maximal affinity model predicts small-molecule druggability. Nat.Biotechnol., 2005, $25: 71-75,2005$

[114] Deaton, D. N. \& Kumar, S. Cathepsin K inhibitors: their potential as anti-osteoporosis agents. Progr. Med.Chem. 42: $245-375,2004$

[115] Navab, R., Pedraza, C., Fallavollita, L., Wang, N., Chevet, E.,Auguste, P., Jenna, S., You, Z., Bikfalvi, A., Hu, J.Loss of responsiveness to IGF-I in cells with reduced cathepsin L expression levels. Oncogene 27:4973-4985, 2008.
[116] Palermo, C. and Joyce, J.A. Cysteine cathepsin proteases as pharmacological targets in cancer. Trends Pharmacol. Sci. 29:22-28, 2008.

[117] Lion, J.M., Mentaverri, R., Rossard, S., Jullian, N., Courtois, B.,Courtois, J., Brazier, M., Maziere, J.C., and Kamel, S.Oligogalacturonic acid inhibit bone resorption and collagen degradation through its interaction with type I collagen. Biochem. Pharmacol,78, 1448-1455, 2009.

[118] Long, M. and Chagnovich, D. Use of cathepsin L antagonists in the treatment of bone diseases. WO Patent WO/2009/076,490, 2009.

[119] Hung CF, Rohani MG, Lee SS, Chen P, Schnapp LM. Role of IGF-1 pathway in lung fibroblast activation. Respir Res, 14:102, 2013.

[120] Tommelein J, Verset L, Boterberg T, Demetter P, Bracke M, De Wever O.Cancer-associated fibroblasts connect metastasis-promoting communication in colorectal cancer. Front Oncol,5:63, 2015.

[121] Hou, W. S., Li, Z., Gordon, R. E., Chan, K., Klein, M. J., Levy, R., Keysser, M., Keyszer, G., \& Brömme, D. Cathepsin $\mathrm{K}$ is a critical protease in synovial fibroblast-mediated collagen degradation. Am. J. Pathol. 159, 2167-2177, 2001.

[122] Ganguly SS, Plattner R. Activation of abl family kinases in solid tumors.Genes Cancer. 3(5-6):414-25, 2012.

[123] Condeelis J, Singer R, Segall JE: The great escape: When cancer cells hijack the genes for chemotaxis and motility. Annual review of cell and developmental biology vol. 21: 695-718, 2005.

[124] Krol, J., Sato, S., Rettenberger, P., Assfalg-Machleidt, I., Schmitt,M., Magdolen, V., and Magdolen, U. Novel bi- and trifunctional inhibitors of tumor-associated proteolytic systems.Biol. Chem. 384:1085-1096, 2003.

[125] Chapman HA, Riese RJ, and Shi GP. Emerging roles for cysteine proteases in human biology. Annu Rev Physiol 59:63-88, 1997.

[126] Boyd, M. J.; Crane, S. N.; Robichaud, J.; Scheigetz, J.; Black, W.C.; Chauret, N.; Wang, Q.; Massé, F.; Oballa, R. $M$. Investigation of ketone warheads as alternatives to the nitrile for preparation of potent and selective Cathepsin $\mathrm{K}$ inhibitors. Bioorg. Med. Chem. Lett. 19: 675-679, 2009.

[127] Fuller, K., Lawrence, K. M., Ross, J. L., Grabowska, U. B., Shiroo, M., Samuelsson, B., \& Chambers, T. J. Cathepsin K inhibitors prevent matrix-derived growth factor degradation by human osteoclasts. Bone 42: 200-211, 2008.

[128] Gocheva V, Zeng W, Ke D, Klimstra D, Reinheckel T, Peters C, Hanahan D, Joyce JA. Distinct roles for cysteine cathepsin genes in multistage tumorigenesis. Genes Dev. 20(5):543-56, 2006.

[129] Tung, C. H., Mahmood, U., Bredow, S., \& Weissleder, R. "In vivo imaging of proteolytic enzyme activity using a novel molecular reporter." Cancer research vol. 60,17: 4953-8, 2000

[130] Lecaille F, Bromme D, Lalmanach G: Biochemical properties and regulation of Cathepsin $\mathrm{K}$ activity. Biochimie, 90:208-226, 2008. 
[131] Pontes J Jr, Srougi M, Borra PM, Dall' Oglio MF, Ribeiro-Filho LA, Leite KR. E-cadherin and beta-catenin loss of expression related to bone metastasis in prostate cancer. Appl Immunohistochem Mol Morphol. 18(2): $179-84,2010$.

[132] Kalluri R, Zeisberg M. Fibroblasts in cancer. Nat Rev Cancer 6: 392-401, 2006.

[133] Xu W, Hu X, Chen Z, Zheng X, Zhang C. Normal fibroblasts induce E-cadherin loss and increase lymph node metastasis in gastric cancer. PloS one vol. 9,5 e97306, 2014

[134] A.K Perl, P Wilgenbus, U Dahl, H Semb, G Christofori A causal role for E-cadherin in the transition from adenoma to carcinoma Nature, 392 :190-193, 1998.

[135] G Strathdee. Epigenetic versus genetic alterations in the inactivation of E-cadherin Semin. Cancer Biol., 12: 373 379,2002 .

[136] K Vleminckx, L Vakaet Jr., M Mareel, W Fiers, F van Roy Genetic manipulation of E-cadherin expression by epithelial tumor cells reveals an invasion suppressor role.Cell, 66:107-119, 1991.

[137] Podhajcer OL, Benedetti L, Girotti MR, Prada F, Salvatierra E, Llera AS: The role of the matricellular protein SPARC in the dynamic interaction between the tumor and the host. Cancer Metastasis Rev,27:523-537, 2008.

[138] Cox OT, O'Shea S, Tresse E, Bustamante-Garrido M, Kiran-Deevi R, O'Connor R.IGF-1 Receptor and Adhesion Signaling: An Important Axis in Determining Cancer Cell Phenotype and Therapy Resistance. Front Endocrinol (Lausanne), 6:106, 2015. 